\title{
Poland, 1980-1984: A witness to history
}

\section{JOHN BURGESS}

The late Francis Stuart, the first Australian Ambassador to be resident in Poland, wrote an interesting book about his long career in the Foreign Service. Towards Coming of Age was published in 1989 and Stuart's reflections on his last post abroad, to Poland, included the following:

It is fanciful to believe that the Soviet leadership would ever question the infallibility of their official doctrine or relinquish the glacis of subordinate states protecting the Soviet borders...Sadly then, Poland and like countries can expect no more freedom in the future than the circumscribed autonomy they have now.

Many would have agreed with him in the late 1980s, but that which he considered fanciful was actually to happen within a few short years. I was fortunate to be a witness to part of this historic transition.

I arrived in Poland as Australian Ambassador on 30 September 1980, about three months after the first strikes and just a month after the signing of the Gdańsk Agreements between Solidarity and the Polish government. I stayed on until the end of 1984.

A previous posting in Moscow had not prepared me for what I found in Poland. The country was in ferment. In Moscow under Brezhnev, the foreign community had been effectively kept in isolation from the local society. Kremlinology had consisted largely of reading between the lines of the tightly controlled Soviet media. In Poland in 1980-81, the local society was not only accessible but positively welcoming and disarmingly outspoken. The Polish media was lifting the lid on what had actually been going on in the country. The inner workings and manifold failings of what professed to be a workers' state were revealed for all to see. 
As a general rule, diplomats study their host country as detached outsiders from a privileged and protected position. Sometimes, however, they will encounter situations where they will feel drawn to take sides. In my case, Poland in 1980-81 was such a situation. A great majority of Poles, whether farmers, workers or university-educated people, were plainly deeply dissatisfied with their party-dominated governments and their Soviet overlords and had come together determined to insist upon a better future. This was not an overnight development but one born out of a very bitter and troubled history as a Soviet satellite since World War II. Just about everyone I met seemed to know their Polish history intimately and to be guided and inspired by it. This was a nation rebelling against the state, and it was hard not to be drawn to a people so dismissive of the odds stacked against them.

I recall no controversy during those years over what Australian policy towards the situation in Poland should be, either within Canberra or between Canberra and the Embassy. Nor do I recall that the Embassy received any strong policy directions from Canberra under the Fraser government. The Embassy's reporting and analysis - generally sympathetic to Solidarity's cause - seemed to be accepted. By and large, Australians in general seemed instinctively sympathetic towards Solidarity's struggle. One unexpected exception that comes to mind was an Australian shipping magnate visiting Poland - much bruised over the years by encounters with Australian unions - who felt sympathy for a government being challenged by a trade union.

It is perhaps worth recording here that in the early 1980s there was little institutional expertise in the Department of Foreign Affairs on Eastern Europe as we then called it. Few resources were devoted to it. Our embassies there were small, including the one in Moscow. The Soviet Union-superpower though it then was-did not loom large in the department's priorities. Junior diplomats might think of carving out a career path in South-East Asia or East Asia, but not in Eastern Europe. I sometimes reflected on the oddness of this low priority. There was the fact of the Soviet Union's superpower status, and there was the further fact that Australia hosted significant minorities from the region - regularly augmented by the periodic eruptions there. These facts argued for more attention on Australia's part. Against this there was of course the perception then, reflected in Francis Stuart's comment above, that the future of this part of the world was fixed and not much could be done about it. None of us knew then that we were witnessing the early stages of one of the key turning points of the twentieth century.

It should be noted at the same time that Australia did not loom large in Poland's thinking, either at government level or in popular estimation. Australia was seen as a friendly place, attractively far away from Poland's geopolitical 
circumstances, a place in which part of the Polish diaspora had been successful in making new lives. While Australia's support was welcome, it was not seen as a country likely to be able to exert much influence on Poland's struggle.

The Australian Embassy was among the more active embassies in Warsaw in seeking out contacts with Solidarity. Some cautious souls in Canberra might have felt the Embassy was going a bit far in this respect, but I recall no reprimands. There was one official complaint lodged by the Polish Ambassador in Canberra, no doubt on instructions from his government. This was after the introduction of martial law, as I recall, and along lines that I was paying inappropriate attention to 'figures in Poland who held no official positions', or words to that effect. Happily, the Ambassador was given short shrift by the department.

Contact with Solidarity was established early. We were fortunate in having a capable and loyal locally engaged staff in the Embassy, a number of whom had useful connections, and some of our early contacts were made with their assistance. Quite a few of those staff now live in Australia. In the period before martial law, we had an enterprising Third Secretary in the Embassy-Kate McGovern, now sadly deceased. She linked up with a friend in the Canadian Embassy, Lillian Thomsen, and the two young women travelled together throughout Poland meeting a wide range of Poles, including many Solidarity activists but also party and government officials and prominent figures in the church. I recall that many of their gallant Polish contacts would not allow them to pay for meals, coffees, and so on, and that their small representation allowances went a very long way.

I believe I first met Lech Wałęsa in February 1981. We had arranged to meet him through Father Henryk Jankowski, a Catholic priest close to Wałęsa at the time and known as the 'rhinestone priest' by the foreign press in Warsaw as he appeared to enjoy living well. I have a strong memory of that first meeting with Wałęsa in a two or three-storey building in Gdańsk - then Solidarity's office. Burly workers were running up and down the narrow stairs and several times our conversation was interrupted as his people burst into our small room to pass on some news to Wałęsa, or seek his approval for something. I do not recall much that was said but I have a memory of a relatively diminutive figure looking like the worker he was, with a poor complexion and wearing a rather greasy brown roll-neck pullover-nothing like the President of 1990. While serious in seeking to respond to questions, he was also given to witty asides that amused his associates. It was clear that his people there hung on his every word. While it was an odd comparison, I remember thinking that if one had been with Lenin in the Smolny Institute in Petrograd in October 1917, the atmosphere might have had something in common with the atmosphere in Gdańsk that day. 
As events in 1981 moved steadily towards a point where something had to give, I spoke with no-one who could confidently foresee how it would end. Certainly, if anyone had then suggested that in 10 years after free elections Wałęsa would be President of Poland, they would have been dismissed with a laugh. It is probably fair to say that the majority opinion among close observers was that the Soviet Union or Warsaw Pact would send forces into Poland to put Solidarity down. While quite unable to foresee the end myself, I did spend some time putting on paper why I thought this was unlikely. It seemed to me that the Soviets would be well aware that in Poland's present aroused mood an intervention along these lines could prove a difficult and bloody business. My reading of the situation - informed partly by the bitter history Poland and Russia shared — was that many Poles, unlike the Czechs in 1968, would fight in this event. This was one occasion when disagreement with my assessment came back from Canberra. It was along the lines that, with the benefit of its greater access to information (read US and British material), Canberra's assessment was that it was very likely that Soviet or Warsaw Pact forces would enter Poland to put down the insurrection.

Regardless of my contrary assessment, there was nothing for it but to be prepared for the worst. We in the Embassy spent a good deal of time planning for the contingency of being caught in Warsaw during a prolonged period of civil strife and a breakdown of services. I had authority to evacuate the Embassy if I thought that should be done but never had occasion to contemplate this seriously. The homes of our 13 or so Australia-based staff (Departments of Foreign Affairs, Trade, Immigration, and Australian Federal Police) and their families were scattered throughout the city and on both sides of the Vistula River, which complicated planning. We set up three rally points our people could try to get to if things became difficult for them: the embassy chancery and my residence, both in Saska Kępa on the eastern side of the river, and the immigration officer's house on the other side of the river. We tested hand-held radio communication between each of them (in the days before mobile phones) and stocked them with supplies from West Berlin, which we thought we might need, including provision for independent means of heating in Warsaw's strong winter. We also embarked on a program of shredding any material that could be a source of embarrassment to us or others. In the event, none of these contingency plans was needed.

In November 1981, not long before martial law was declared, the very first visit of an Australian Foreign Minister to Poland took place. This late timing of a first visit is an indication of the relatively low priority Poland had had for Australian governments until then. Foreign Minister, Tony Street, and accompanying party came on an official visit for a few days. Because of the fortuitous timing, Street was able to meet with Prime Minister Jaruzelski, Primate Glemp and Wałęsa- 
the last meeting arranged privately at the Australian residence but with the knowledge of the Polish government. These were the key figures inside Poland who held the future of the country in their hands at the time. Of course, no indication was given in any of these meetings that in a few short weeks Poland would be under martial law.

Martial law was declared on 13 December 1981 and was very effectively executed by Polish forces under Jaruzelski. One of the surprising things about it was that while it must have required detailed planning over a considerable time, it managed to achieve near total surprise. Thousands of Solidarity activists, including most of the top leadership, were taken into custody overnight. With people stunned by the unexpected action by forces in Polish uniforms, little bloodshed occurred.

I was in Sosnowiec, not far from Poland's southern border, on the night of 12/13 December 1981. I was as surprised as anyone by the declaration and I recall that the US Ambassador happened to be outside Poland at the time. My wife, our four young children and I had stayed the night in a hotel on our way to a much anticipated skiing holiday in Austria. We heard the news on the BBC at six o' clock in the morning while still in bed. When I went down to the lobby of the hotel, Jaruzelski's declaration of martial law was being broadcast over and over again. There were quite a lot of people in the lobby but, in my memory, they were all very still, stunned, listening to the broadcast. Some were weeping. I remember it as a tableau vivant. We drove back to Warsaw that morning thinking we might encounter some difficulties along the way but went straight through without incident. There were no roadblocks, just a few tanks parked here and there.

Being in Warsaw during martial law was a strange experience. The city was in the grip of a hard winter. I recall heavy hoarfrost on the bare trees, and braziers at snowy crossroads to warm the soldiers on duty there. A curfew was in place between $10 \mathrm{pm}$ and $6 \mathrm{am}$. The plug had been pulled on the city's telephone system in a time before mobile telephones. Appointments could not be made without difficulty and it was often necessary to go in search of those you wanted to see in the hope of finding them in. News of what was happening outside Warsaw was scarce.

Fortunately, in the months before martial law, Canberra had provided the Embassy with independent communications allowing us to send and receive short messages to and from the department. The first need in a situation like the one we faced was to be able to let those at home know that their Australian relatives in Poland were safe. 
I stayed on in Poland for a full three years after martial law was declared, fully expecting that I might witness the next social explosion, which then seemed only a matter of time. It was a time marked by sizeable anti-government demonstrations on significant Polish anniversaries, which brought inevitable clashes with the security forces. A detailed account of these developments has been well told by others and is beyond the scope of this memoir.

It is perhaps worth reflecting though, in the light of almost 30 years of developments in Poland since, whether Jaruzelski's declaration of martial law can be seen as having in fact been in Poland's interest at the time. Clearly, he had a need to save his own authority, but I would think Jaruzelski also saw himself as acting in Poland's interest. Unpalatable as this thought would have been to me in 1981, I can now see that a case can be made that the General saw nothing but worse alternatives for Poland than his 'self-invasion'. The case for Jaruzelski has been greatly aided of course by the then unforeseen collapse of the Soviet Union within the decade and the favourable developments in Poland since. The fanciful thought of Francis Stuart, noted in the opening paragraph, had come to pass. In retrospect, we might even see the Soviet Union's apparent reluctance to act decisively to put down the challenge in Poland as an early sign that it had lost the will to defend its empire.

In conclusion, I record a few other memories that have stayed with me from those years in Poland.

A note on a scrap of paper received in early 1982 after I had got a message to the imprisoned Janusz Onyszkiewicz, former spokesman for Solidarity, asking if there was anything he needed. In my memory, his response read: 'a tin of Three Nuns pipe tobacco, a bottle of Johnny Walker and a war game' - all duly delivered. On a visit to Poland years later, I called on him as Poland's ViceMinister of Defence.

The outspoken young priest Jerzy Popiełuszko, leaning against a sunlit wall and holding court at a gathering in the Australian residence. He was to be brutally murdered by security policemen in October 1984.

A drive south-east to Przemyśl through snow-covered countryside to meet with the then Bishop Tokarczuk, who proudly showed us his photograph albums filled with pictures of the many churches he had built and who talked of his concern for Poles on the other side of the border, in the Ukraine.

The priest of the huge modern church at Nowa Huta, near Kraków, mischievously describing his church as 'an Ark in a red sea'. 
A Polish neighbour arriving late one evening to pass over documents relating to the academic qualifications of his daughter. She was visiting China when martial law was declared, had made contact with the Australian Embassy in Beijing and was heading to Australia to live.

And not least among many contacts with many remarkable people, the always fruitful meetings, in Canberra and in Poland, with the late Jerzy Zubrzycki. He would have been the first person I asked to look over this memoir. 